DOI: $10.12775 / M B S .2014 .002$

Medical and Biological Sciences, 2014, 28/1, 11-15

ORIGINAL ARTICLE / PRACA ORYGINALNA

Julia Feit ${ }^{1,2}$, Edward Jacek Gorzelańczyk ${ }^{1,2,3}$

\title{
EFFECT OF A SINGLE DOSE OF METHADONE ON SACCADIC REFIXATIONS IN OPIOID ADDICTED SUBJECTS
}

\author{
WPŁYW POJEDYNCZEJ DAWKI METADONU NA REFIKSACJĘ SAKADYCZNĄ \\ U OSÓB UZALEŻNIONYCH OD OPIOIDÓW
}

\author{
${ }^{1}$ Department of Theoretical Basis of Bio-Medical Sciences and Medical Informatics, \\ Nicolaus Copernicus University in Torun, Collegium Medicum in Bydgoszcz \\ Head: prof. Krzysztof Stefański \\ ${ }^{2}$ Non-public Health Care Center Sue Ryder Home in Bydgoszcz, \\ Scientific Research Department \\ Head: Assoc. prof. Edward Jacek Gorzelańczyk \\ ${ }^{3}$ Polish Academy of Sciences, Institute of Psychology \\ Head: Assoc. prof. Urszula Jakubowska
}

\section{S u m m a ry}

Introduction: Eye movements are closely related to cognitive and emotional functions. Information on saccadic dynamics during certain tasks may indicate disorders of mental functions, which can help to explain the neurobiology of sensory-motor systems and can be useful in neuropsychiatric diagnosis.

Aims/ Objectives: The study aims at assessing the impact of a single therapeutic dose of methadone on eye movements (saccades) dynamics in HIV $(+)$ and HIV(-) opioid addicted subjects.

Methods: Sixty patients from the substitution program were examined. The Latency Test (LT), carried out with the use of saccadometer diagnostic system, was conducted twice: before and 1.5 hours after the administration of a therapeutic dose of methadone. In both parts of the test mean peak velocity, mean latency, mean duration, mean amplitude were measured.

Results: The mean duration of latency in HIV(-) subjects measured by LT after the administration of a therapeutic dose of methadone was statistically significantly increased whereas the mean peak velocity was decreased. The mean peak velocity latency in $\mathrm{HIV}(+)$ subjects is not statistically significant. The mean duration and the amplitude of latency after the administration of a therapeutic dose of methadone is statistically significant in opioid addicted $\mathrm{HIV}(+)$ subjects . It was found that the mean peak velocity before the administration of a therapeutic dose of methadone was statistically significantly different in HIV(-) subjects as compared to $\operatorname{HIV}(+)$ ones.

Conclusion: An increase in the values of saccadic refixation parameters in opioid addicted subjects after the administration of a therapeutic dose of methadone was observed. An improvement in saccadic refixations parameter in HIV(-) subjects after the administration of a therapeutic dose of methadone was concluded.

\section{Streszczenie}

Wstęp: Motoryka gałek ocznych jest ściśle związana z funkcjami poznawczymi i emocjonalnym dlatego informacje dotyczące dynamiki sakad podczas wykonywania określonych zadań mogą świadczyć o fizjologii bądź zaburzeniach funkcji psychicznych co może pomóc w wyjaśnieniu neurobiologii układów sensoryczno-motorycznych i być przydatne 
w diagnostyce neuropsychiatrycznej.

Cel: Badania mają na celu stwierdzenie czy podanie pojedynczej dawki leku substytucyjnego wpływa na dynamikę sakad oraz czas latencji u osób uzależnionych od opioidów $\mathrm{HIV}(+)$ i HIV (-)

Materiały i metody: Zbadano 60 pacjentów programu substytucyjnego. Wykonano test refiksacji sakadycznej - Latency test (LT) za pomocą systemu diagnostycznego Saccadometr dwukrotnie: przed podaniem oraz około 1,5 godziny po podaniu leczniczej dawki metadonu. W obu częściach testu zmierzono prędkość sakad, średni czas latencji, średni czas trwania sakad, średnią amplitudę sakad. Wyniki: W grupie osób uzależnionych od opioidów HIV(-) w teście LT stwierdzono, że średni czas trwania sakad był istotnie statystycznie $(\mathrm{p}<0,01)$ dłuższy, a prędkość maksymalna sakad

Key words: opiates, methadone, saccadic refixation, saccades HIV.

Stowa kluczowe: opioidy, metadon, refiksacja sakadyczna, sakady, HIV.

\section{INTRODUCTION:}

Addictions are based on a complex mechanism consisting of activation, modification and stimulation of opioid receptors, changes in the metabolism of opiates and many other factors that are not fully elucidated. Opioids are among the group of psychoactive substances with very strong mental and physical addictive potential [1,2]. Taking opioids is associated with adaptive changes in the nervous system $[3,4]$. The increase in tolerance is associated with increased doses, often far in excess of the initial toxic dose of opioid [5]. After weaning an opioid substance withdrawal syndrome is observed, characterized by hyperactive neurons compensation $[5,6]$. Using an opioid leads to changes in the brain's neurotransmitter balance (dopaminergic signalling), and hence impairment in proper brain functioning, mainly affecting the subcortical parts of the forebrain - the striatum and the basal ganglia occurs $[7,8]$. This causes deterioration of psychomotor abilities observable at the behavioural level. The striatum plays a role of a relay station forwarding information from the cerebral cortex into the basal ganglia -a group of subcortical nuclei involved in motor, cognitive and emotional control [9]. Subsequently, the information is fed back into the cortex via the thalamus. There are at least five such control loops linking the subcortical nuclei with cerebral cortex: motor, oculomotor, dorsolateral prefrontal, lateral orbitofrontal, and limbic. Any dysfunction of these loops, as observed in several psychiatric disorders, as well as in psychoactive substance addiction, results in emotional, motor and cognitive impairment $[9,10,11]$.

\section{MATERIAL AND METHODS:}

Sixty patients from the substitution program were examined. The study included 24 women and 36 men (mean age $39 \pm 7.7$ years) including $29 \mathrm{HIV}(-)$ subjects and $31 \mathrm{HIV}(+)$ ones treated in methadone substitution program during an average period of 53 months. The study was conducted twice: before and about 1.5 hours after administration of therapeutic doses of methadone. All the subjects performed the saccadic refixation test twice.

In the research the effects of deep brain stimulation, carried out in order to change the saccadic parameters, were analyzed. Saccadometer is a diagnostic system enabling identification of impairment of the central nervous system functioning at the earliest (presymptomatic) stages of a disorder. The analysis of oculomotor impairment allows determining interrelations between motor, emotional and cognitive functions. The system enables to perform strictly quantitative mniejsza po podaniu metadonu. Natomiast w grupie osób HIV $(+)$ uzależnionych od opioidów nie stwierdzono istotnej statystycznie różnicy w prędkości maksymalnej. Wykazano w grupie osób HIV $(+)$ po podniu matadonu istotność statystyczną w czasie trwania skad oraz amplitudzie sakad. Stwierdzono, że prędkość maksymalna różni się istotnie statystycznie przed podaniem metadonu u osób HIV(-) leczonych w programie substytucyjnym w porównaniu do osób HIV(+).

Wnioski: Wyniki badań potwierdzają zmiany w dynamice sakad, a także zmiany w latencji odpowiedzi na bodziec po podaniu pojedynczej dawki metadonu w grupach badanych. Stwierdzono poprawę parametrów refiksacji sakadycznej osób uzależnionych od opioidów HIV (-) po podaniu leczniczej dawki metadonu. evaluation of saccadic dynamics measuring eye movement in the near infrared technology (Infra-Red Oculography) $[11,12,13]$. The system measures eye movements in horizontal axis with high temporal and spatial resolution. The eye stimuli (for subjects' visual system stimulation) are displayed using miniature laser projectors mounted on the sensor forehead plate. A visual stimulation allows carrying out a number of tests for fast eye movements (saccades) research. In all the tests the system gives opportunity to set numerous trials or test duration according to the examination needs. The tests results (saccadic latency, duration, peak velocity and simplified position profile) are stored in the device's memory and can be reviewed right after the test is finished [12].

\section{RESULTS:}

The saccadic refixations test - Letency Test (LT) was conducted twice: before the administration, and about 1.5 hours after the administration of a therapeutic dose of methadone (mean daily dose of methadone: $71.9 \pm(33.4) \mathrm{mg}$ ). In both parts of the test saccadic velocity was measured, which is perceived as a difference in time between the beginning of a saccadic movement and the drop in the velocity of an eye movement below $5 \mathrm{deg} / \mathrm{s}$. Mean latency, mean duration, and mean amplitude were also measured in the test. It was found that the average latency time before methadone administration was $204.2 \pm(64.2) \mathrm{ms}$, whereas after the administration of a therapeutic dose of methadone average latency time was $207.8 \pm(58.9) \mathrm{ms}$. The statistical analysis shows that the mean latency was not statistically significant.

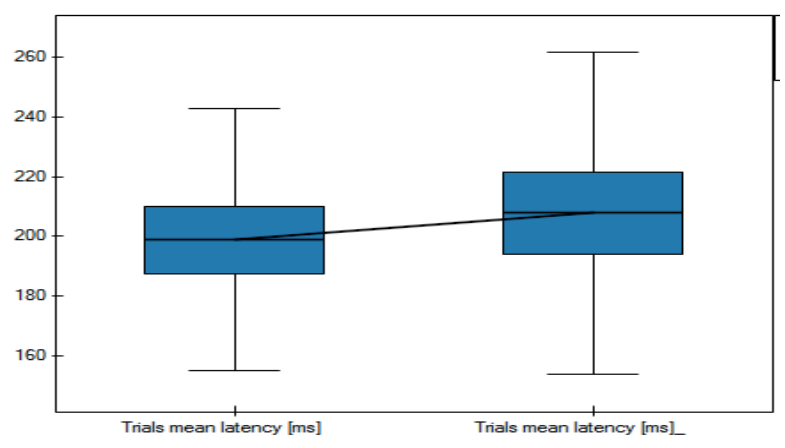

fig. 1. Comparison of the mean latencies of the Latency Test before and after the administration of methadone.

ryc. 1. Porównanie średniego czasu latencji w teście refiksacji sakadycznej przed i po podaniu metadonu. 
There was a statistically significant difference in the average velocity of saccades $(p=0.03)$ after the administration of a therapeutic dose of methadone. The results were verified by Student's t test for dependent samples $(t=2.24)$.

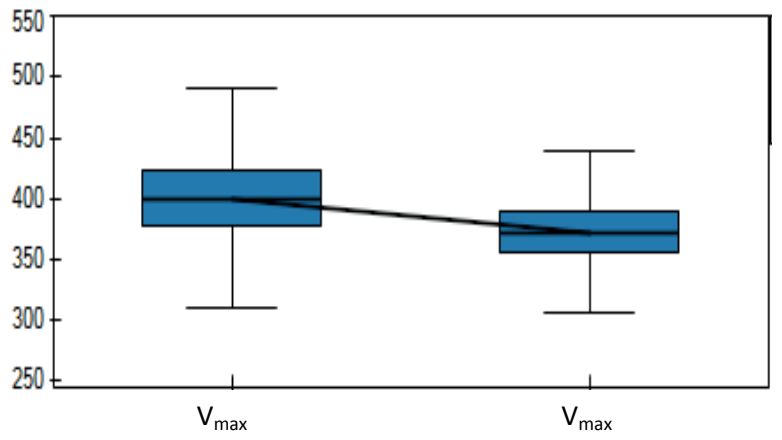

fig. 2. Comparison of the mean peak velocities of the Latency Test before and after the administration of methadone.

ryc. 2. Porównanie średniej prędkości maksymalnej w teście refiksacji sakadycznej przed i po podaniu metadonu.

It was observed that the mean amplitude of the test decreased after the administration of methadone but the values were not statistically significant.

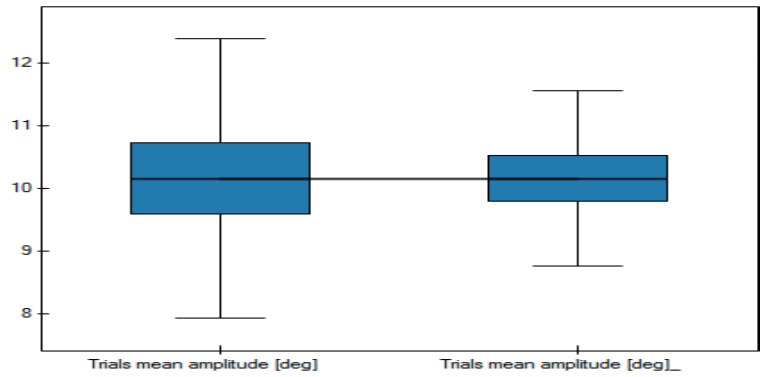

fig. 3. Comparison of the mean amplitudes of the Latency Test before and after the administration of methadone.

ryc. 3. Porównanie średniej amplitudy sakad w teście refiksacji sakadycznej przed i po podaniu metadonu.

The increase of the mean duration values in opioid addicted subjects after the administration of a therapeutic dose of methadone was observed. The statistical analysis revealed that the duration decreased significantly after methadone.

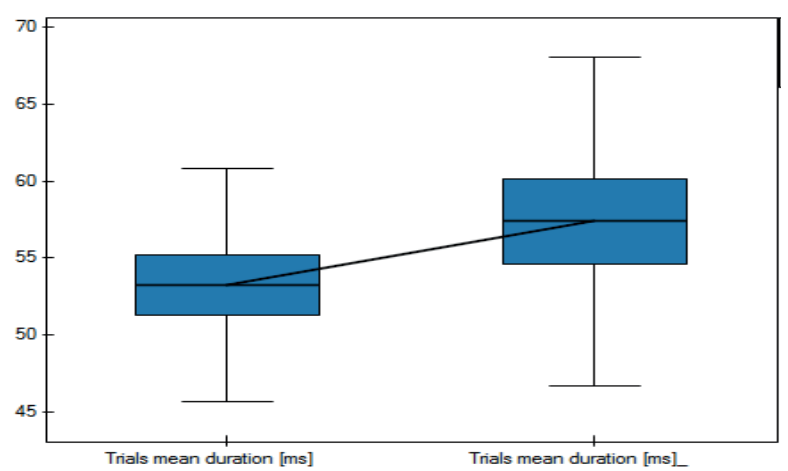

fig. 4. Comparison of the mean durations of the Latency Test before and after the administration of methadone.

ryc. 4. Porównanie średniego czasu trwania sakad w teście refiksacji sakadycznej przed i po podaniu metadonu.
Among the members of the study groups who were addicted to opioids $\mathrm{HIV(-)}$ and $\mathrm{HIV}(+)$ participants of the substitution program were distinguished. Statistical analysis of the same Latency Test parameters: mean peak velocity, mean latency, mean duration, mean amplitude were performed. The statistical analysis shows that the mean latency and the mean duration measured by the Latency Test after the administration of a therapeutic dose of methadone increased in both groups but were not statistically significant.

Latency test - średni czas latencji/mean latency

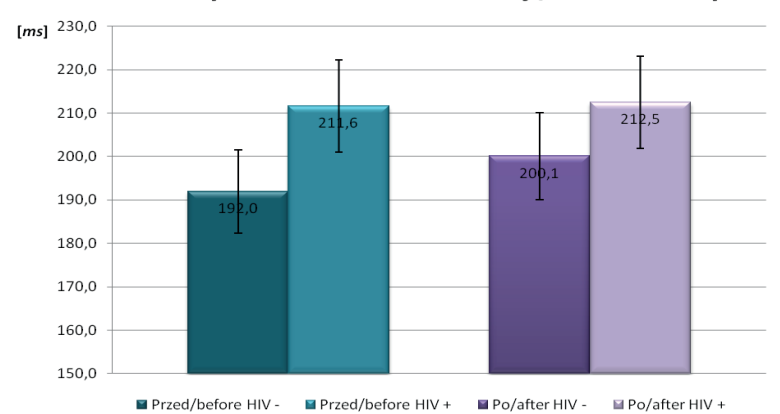

fig. 5. Comparison of the mean latencies of the Latency Test before and after the administration of methadone in HIV(+) and HIV(-) subjects.

ryc. 5. Porównanie średniego czasu latencji w teście refiksacji sakadycznej przed i po podaniu metadonu u osób HIV(+) i osób HIV(-)

[ms]

\section{Latency test - średni czas trwania sakad/mean duration}

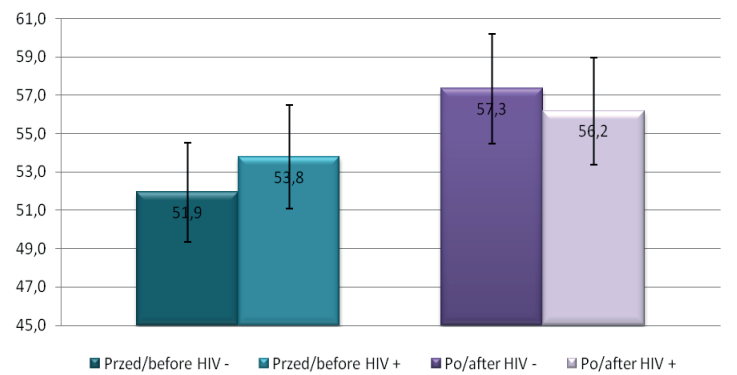

fig. 6. Comparison of the mean durations of the Latency Test before and after the administration of methadone in $\mathrm{HIV}(+)$ and HIV(-) subjects.

ryc. 6. Porównanie średniego czasu trwania sakad w teście refiksacji sakadycznej przed i po podaniu metadonu u osób HIV (+) i osób HIV(-)

Before the administration of methadone the mean amplitude and the mean peak velocity of the Latency Test differed statistically significantly in HIV(-) patients treated with substitution drug compared to $\mathrm{HIV}(+)$ individuals from the program. 


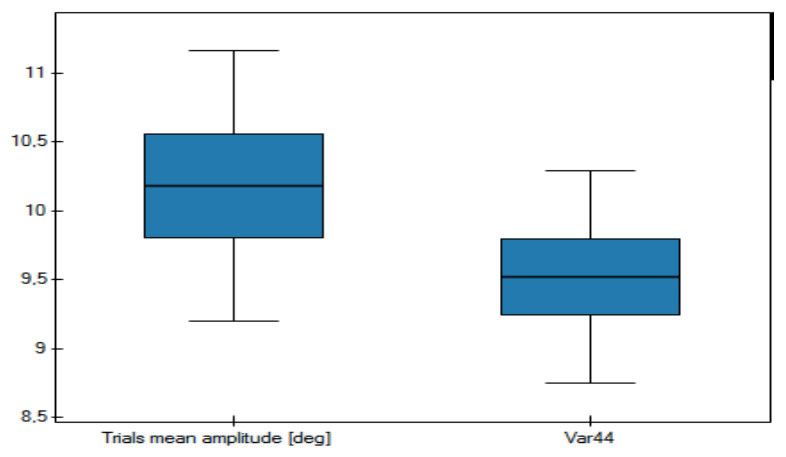

fig. 7. Comparison of the mean amplitudes of the Latency Test before the administration of methadone in HIV(+) and HIV(-) subjects.

ryc. 7. Porównanie średniej amplitudy sakad w teście refiksacji sakadycznej przed podaniem metadonu u osób HIV(+) i osób $H I V(-)$

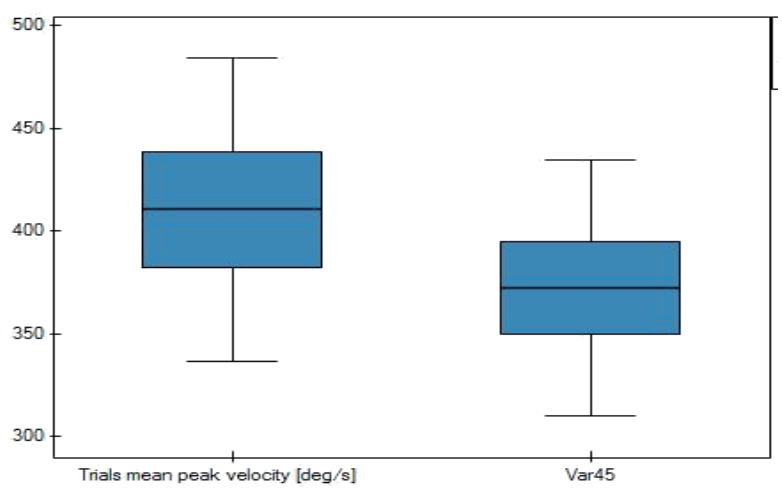

fig. 8. Comparison of the mean peak velicities of the Latency Test before the administration of methadone in HIV(+) and HIV(-) subjects.

ryc. 8. Porównanie średniej prędkości maksymalnej sakad w teście refiksacji sakadycznej przed podaniem metadonu u osób $H I V(+)$ i osób HIV (-)

The statistical analysis confirms the change in the saccadic refixations parameter in opioid addicted subjects. A therapeutic dose of methadone has a weak effect on subjects infected with HIV virus. Interactions of antiretroviral drugs and methadone can lead to changes in the blood methadone concentrations influencing the regulation of oculomotor activity at the same time.

\section{DISCUSSION:}

According to the concepts of regulation of mental activity by cortico-subcortical loops, proper operation of all the structures constituting the loop is a prerequisite for their proper functioning [14]. The oculomotor loop participates in the control of saccadic eyeball movements. Efferent connections to the superior colliculus (Sc) from the cortical areas of the brain and subcortical nuclei, especially the reticular part of substantia nigra $(\mathrm{SNr})$, make it possible to control rapid eyeball movements through the inhibition of movements disturbing the execution of a task [15]. Chronic use of psychoactive substances can lead to structural and functional changes in the central nervous system [16]. Opioid addicted subjects may experience symptoms similar to those in people with changes in the cerebral cortex $[16,17]$. In order to investigate oculomotor disorders in people addicted to psychoactive substances test, parameters of eye movements were used as a marker to assess the impact of psychoactive substances on the central nervous system (CUN) [18,19]. The study and the analysis of the Latency Test results have confirmed that the mean peak velocity in opioid addicted subjects is significantly shorter after the administration of methadone. The mean duration increases significantly after methadone in opioid addicted subjects. However, no statistical significance was noticed when comparing the mean latency and the mean amplitude after methadone. The results may indicate that the administration of a therapeutic dose of methadone reduces psychomotor functions in opioid addicted subjects. This is consistent with the hypothesis that changes in dynamics and latency time are observed in addicted individuals after administration of a therapeutic dose of methadone. This is confirmed by the results of other authors. A study was conducted among individuals taking benzodiazepines, ethanol, opiates, amphetamines $[18,19,20]$. It was demonstrated that there were negative linear correlations between peak velocity and visual-spatial coordination in subjects receiving psychoactive substances. Changes in the mean peak velocity and the mean duration after the administration of a psychoactive substance were observed in all the subjects [18,21]. Chronic use of psychoactive substances may lead to structural and functional changes in the central nervous system that can cause cognitive dysfunction [19,20,21].

Among opioid addicted individuals being treated with methadone $\mathrm{HIV}(+)$ and $\mathrm{HIV}(-)$ subjects were distinguished. A statistical analysis of the same latency test parameters was performed. It has been found that the mean amplitude and the mean peak velocity are statistically significantly lower before the administration of methadone in $\operatorname{HIV}(+)$ patients than after it. After the administration of methadone latency test parameters are improved, but the changes are bigger in HIV (-) individuals. These results might suggest impaired impact of methadone on the saccadic refixation parameters values in $\mathrm{HIV}(+)$ subjects as compared to $\mathrm{HIV}(-)$ ones. In people with HIV infection impaired motor functions, which are a consequence of the negative effects of the virus on the central nervous system, were observed [21,22]. The results of other authors indicate that HIV causes neurocognitive dysfunction across infiltrating CNS in the initial phase, the consequence of which is a damage in the hippocampus, caudate nucleus, and basal ganglia $[22,23]$. Eyeball movements disorder is probably related to the neurotrophic effects of HIV leading to damage in the striatum, which plays an important role in psychomotor functions. Furthermore, interactions of antiretroviral drugs and methadone can lead to changes in the blood methadone concentrations influencing the regulation of psychomotor activity at the same time $[21,24]$.

In the recent years in the research on addiction, studies using brain neuroimaging method have been developed in particular. Due to this it has been proven that addiction is not a disorder of willpower, but a disease of the brain. These methods confirm that both psychotherapy and drug therapy change the brain activity by changing the severity of symptoms in psychiatric disorders, also in the case of addictions [25]. 


\section{CONCLUSION:}

- Lengthening of the average duration of saccades and a reduced mean peak velocity after the administration of methadone was concluded, which reflects deterioration in psychomotor functions.

- Methadone influence saccadic dynamics parameters less in HIV(+)than in HIV(-) drug users.

\section{REFERENCES:}

1. Anthony J. C., Warner L., Kessler R. Comparative epidemiology of dependence on tabacco, alcohol, controlled substances and inhalants: Basic findings from the National Comorbidity Survey. Experimental and Clinical Psychopharmacology 1994, 2(3), 244-68.

2. Teesson M., Hall W., Degenhardt L. Uzależnienia - Modele kliniczne i techniki terapeutyczne. 2005, GWP, Gdańsk.

3. Connor M., Christie MD. Opioid receptor signalling mechanisms. Clin.Exp. Pharmacol. Physiol. 1999, 26, 493-9.

4. Law P.Y., Wong Y.H., Loh H.H. Molecular mechanisms and regulationof opioid receptor signaling. Annu. Rev. Pharmacol. Toxicol. 2000, 40, 389-430.

5. Tso P.H., Wong Y.H. Molecular basis of opioid dependence: role of signal regulation by G- proteins. Clinical and Experimental Pharmacology and Physiology. 2003, 30 (5-6), 307-316

6. Mierzejewski P., Kostowski W. Zmiany adaptacyjne wywołane długotrwałą ekspozycja na opiaty. Rola układu antyopioidowego. Alkoholizm i narkomania. 2001, 14 (4), 451-460.

7. Kalivas PW, Peters J, Knackstedt L (2006) Animal models and brain circuits in drug addiction. Molecular Interventions, 6(6): 339-44

8. Kelley AE (2004) Memory and addiction: shared neural circuitry and molecular mechanisms. Neuron 44: 161-179.

9. Laskowska I, Gorzelańczyk EJ (2009) Rola jąder podstawy w regulacji funkcji poznawczych. Neuropsychiatria i Neuropsychologia; 4, 1: 26-35.

10. E.J. Gorzelańczyk, Neurobiological sources of addiction - evolutionary and clinical perspective, Alkoholizm i Narkomania 2011, Tom 24, nr 3, pp. 235-249

11. Edward Jacek Gorzelańczyk: Functional anatomy, physiology and clinique of bas. Neuroimaging for Clinicians - Combining Research and Practice, 2011, 89106, ISBN 978-953-307-450-4.

12. Ober J.K., Przedpelska-Ober E., Gryncewicz W., Dylak J., Carpenter R.S., Ober J.J. Hand-held system for ambulatory measurement of saccadic durations of neurological patients. In: Gadja J., ed. Modellingand Measurement in Medicine. PAN, Warsaw; 2003:187-198.

13. Pearson BC, Armitage KR, MCW, S RH. Saccadometry: the possible application of latency distribution measurement for monitoring concussion. Br J Sports Med. 2007; 41(9): 610-612.

14. Brown L.L., Schneider J.S., Lidsky T.I., Sensory and cognitive functions of the basal ganglia. Current Opinion in Neurobiology 1997, 7, 157-163.

15. Hikosaka O, Takikawa Y, Kawagoe R (2000) Role of the basal ganglia in the control of purposive saccadic eye movements. Physiological Reviews, 80: 953-978.

16. Pirastu R., Fais R., Messina M., Bini V., Spiga S., Falconieri D., Diana M. Impaired decision-making in opiate- dependent subjects: Effect of pharmacological therapies. Drug and Alcohol Dependence, 2006, 83, 163-168.

17. Fukui H., Murai T., Fukuyama H., Hayashi T., Hanakawa T. Functional activity related to risk anticipation during performance of the Iowa gambling task. NeuroImage, 2005, 24, 253-259.

18. Griffiths A. N., Marshall R. W., Richens A. Saccadic eye movement analysis as a measure of drug effects on human psychomotor performance. Br. J. clin. Pharmac. 1984, 18, $73-82$.

19. Rothenberg S., Schottenfeld S., Gross K., et al. Specific oculomotor deficit after acute methadone. Psychopharmacology. 1980, 67(3), 221-227.

20. Zacny, James P. A review of the effects of opioids on psychomotor and cognitive functioning in humans. Experimental and Clinical Psychopharmacology, 1995, 3(4), 432-466

21. Ogden E.J.D. Moskowitz H. Effects of Alcohol and Other Drugs on Driver Performance. Traffic Injury Prevention. 2004, 5(3), 185-198

22. Ghafouri M., Amini S., Khalili K., et al. HIV-1 associated dementia: symptoms and causes. Retrovirology. 2006, $3(28), 1-11$.

23. Fitting S., Ruqiang $\mathrm{Xu}$, Bull $\mathrm{C}$, et al. Interactive comorbidity between Opioid Drug Abuse and HIV-1 Tat. The American Journal of Pathology. 2010, 177(3), $1397-$ 1410

24. Gaskill J.P., Calderon T.M., Luers A.J., et al. Human Immunodeficiency Virus (HIV) Infection of Human Macrophages Is Increased by Dopamine. The American Journal of Pathology. 2009, 175(3), 1148-1159.

25. Erickson C.K. Nauka o uzależnieniach. Wydawnictwa Uniwersytetu Warszawskiego, Warszawa 2010.
Address for correspondence:

Julia Feit

NZOZ Dom Sue Ryder

ul. Roentgena 3

85-796 Bydgoszcz

tel. 608-639-983

fax 523206185

e-mail: j.feit@domsueryder.org.pl

Received: 13.11.2012

Acceoted for publication: 07.01.2014 